\title{
Pelatihan Perhitungan Biaya Produk Utama dan Sampingan pada Badan Usaha Milik Desa di Desa Kerinjing, Kabupaten Ogan Ilir
}

\author{
Burhanudin $^{1 *}$, Yusnaini $^{1}$, Arista Hakiki ${ }^{1}$ dan Sri Maryati ${ }^{1}$ \\ ${ }^{1}$ Fakultas Ekonomi, Universitas Sriwijaya, Sumatera Selatan, Indonesia \\ *Email korespondensi: burhanudin@fe.unsri.ac.id
}

Info Artikel: Diterima: 15 Agustus 2020; Disetujui: 20 September 2020; Dipublikasi: 16 Oktober 2020

\begin{abstract}
Abstrak: Pengabdian pada masyarakat ini bertujuan untuk memberikan pemahaman melalui pelatihan mengenai bagaimana perhitungan biaya produk utama dan produk sampingan BUMDES desa Kerinjing Kabupaten Ogan Ilir Sumatera Selatan. Melalui pelatihan tersebut diharapkan produk-produk yang dihasilkan oleh BUMDES pada desa tersebut dapat diperoleh biaya produksi yang lebih tepat baik untuk produk utama dan produk sampingan. Melalui pelatihan tersebut, diharapkan BUMDES mampu dan terampil dalam mengelola keuangan terkait penentuan biaya produk utama dan sampingan. Dengan demikian diharapkan kinerja keuangan BUMDES dapat terukur dengan baik. Metode pelatihan dilakukan dengan memberikan tutorial penjelasan mengenai konsep dan teori dalam penentuan biaya produk. Selanjutnya dilakukan sesi diskusi yang membahas permasalahan BUMDES yang terkait dengan penentuan biaya produk utama dan produk sampingan yang mereka hasilkan.
\end{abstract}

Kata kunci: Biaya bersama; Harga Pokok Produksi; Produk Utama; Produk Sampingan

Kutipan:

Burhanudin, B., Yusnaini, Y., Hakiki, A., \& Maryati, S. (2020). Pelatihan Perhitungan Biaya Produk Utama dan Sampingan pada Badan Usaha Milik Desa di Desa Kerinjing Ogan Ilir. Sricommerce: Journal of Sriwijaya Community Services, 1(2): 79-84. DOI: https://doi.org/10.29259/jscs.v1i2.15

\section{PENDAHULUAN}

BUMDes lahir sebagai suatu pendekatan baru dalam usaha peningkatan ekonomi desa berdasarkan kebutuhan dan potensi desa. Pengelolaan BUMDes sepenuhnya dilaksanakan oleh masyarakat desa, yaitu dari desa, oleh desa, dan untuk desa. Cara kerja BUMDes adalah menampung kegiatan-kegiatan ekonomi masyarakat dalam sebuah bentuk kelembagaanatau badan usaha yang dikelola secara profesional, namun tetap bersandar pada potensi asli desa, sehingga dapat menjadikan usaha masyarakat lebih produktif dan efektif.

Permasalahan yang dihadapi dalam proses produksi badan usaha milik desa antara lain adalah penentuan harga pokok produksi yang akurat. Banyak Badan Usaha Milik Desa yang kurang memperhatikan bagaimana menentukan biaya produksi untuk produk utama dan produk sampingan yang tepat untuk produk yang mereka hasilkan. Hal ini dikarenakan kurangnya pengetahuan mengenai jenis-jenis biaya dan bagaimana memposisikan biaya dalam penentuan harga pokok. Fokus permasalahan yang dihadapi pada BUMDes adalah bagaimana menentukan biaya produksi produk utama dan produk sampingan dengan tepat. Dengan demikian permasalahan yang dihadapi antara lain adalah kesiapan pemahaman sumberdaya manusia, pembukuan yang diperlukan, dokumentasi atau formulir yang mendukung proses tersebut. 
Masyakarat Desa Kerinjing kabupaten Ogan Ilir, hampir 100 persen beragama Islam. Desa ini dipimpin oleh kepala Desa bernama Usman Umar, memiliki wilayah 4 RT dan 2 Dusun. Potensi yang ada didesa Kerinjing tidaklah cukup banyak tetapi dengan sentuhan bantuan dari pihak yang terkait, potensi desa tersebut dapat dikembangkan terutama dibidang pertanian dan perkebunan. Sebanyak 49 \% penduduk desa berpendapatan dari hasil pertanian dan perkebunan, lahan persawahan dengan luas $\pm 84 \mathrm{Ha}$ dan lahan perkebunan seluas $\pm 105 \mathrm{Ha}$ yang dapat dijadikan aspirasi pemerintah untuk membantu para petani dalam meningkatkan produktifitas hasil pertanian dengan didukung sarana dan prasarana yang memadai. Potensi didesa dibidang kesehatan seperti POSKESDES, POSYANDU dan BIDES, dari potensi ini memang sangatlah dibutuhkan masyarakat yang maju menuju Ogan Ilir sehat. Dari bidang ekonomi potensi desa juga dapat dilihat dari usaha-usaha keluarga seperti pembuatan pakaian (penjahit), usaha angkutan umum, warung-warung sembako, sedangkan potensi dibidang sarana dan prasarana seperti jalan desa yang cukup panjang, sarana pendidikan. Potensi perikanan yang ada didesa Kerinjing cuma nelayan penangkap ikan sawah liar dan sebagian membudidayakan ikan air tawar, dibidang SDM masih banyak SDM yang terampil tetapi tidak bisa menggunakan keahliannya pada umum karena tidak didukung dengan pendidikan keterampilan yang memadai dan persaingan kerja yang banyak.

Variasi atau ragam karakteristik desa terdiri dari kekayaan alam desa, sumberdaya manusia yang ada, jenis matapencaharian dan lain sebagainnya. Demikian juga jenis produk yang dihasilkan dari badan usaha milik desa. Jenis produk yang berbeda tersebut membutuhkan pemahaman yang tepat dalam proses penyusunan harga pokok produksi. Menurut Hansen dan Mowen (2009), menyatakan harga pokok produksi (cost of goods manufactured) mencerminkan total biaya barang yang diselesaikan selama periode berjalan. Sedangkan menurut Blocher dkk (2000), menyatakan harga pokok produk yang diproduksi/ harga pokok produksi (cost of goods manufactured) adalah harga pokok produk yang sudah selesai dan ditransfer ke produk dalam proses pada periode berjalan. Menurut Horngren, et al (2008) mendefinisikan harga pokok produksi (cost of goods manufactured) adalah biaya barang yang dibeli untuk diproses sampai selesai, baik sebelum maupun selama periode akuntansi berjalan.

Menurut Mulyadi (2012), menyatakan harga pokok produksi merupakan pengorbanan sumber ekonomi dalam pengolahan bahan baku menjadi produk jadi. Dengan demikian diharapkan badan usaha milik desa dapat menentukan harga pokok yang tepat dan mengurangi ketidakpastian dalam penentuan harga jual. Pada akhirnya laba yang dihasilkan oleh badan usaha milik desa juga dapat diprediksi dan dihitung dengan benar. Untuk itu Universitas Sriwijaya melakukan pengabdian masyarakat selain sebagai bentuk perwujudan Tri Dharma Perguruan Tinggi maka bentuk pengabdian ini juga dapat dijadikan sebagai upaya bentuk percepatan dan bantuan kepada pemerintah dalam menyalurkan dana desa. Badan Usaha Milik Desa yang menjadi sasaran kami adalah BUMDes yang ada di desa Kerinjing Kabupaten Ogan Ilir Provinsi Sumatera Selatan.

\section{STUDI PUSTAKA}

\subsection{Produk Utama dan Produk Sampingan}

Istilah produk sampingan umumnya digunakan untuk mendefinisikan suatu produk dengan total nilai yang relatif kecil dan dihasilkan secara simultan atau bersamaan dengan produk lain yang nilainya lebih besar. Produk dengan nilai yang lebih besar itu, biasanya disebut produk utama (main product), biasanya diproduksi dalam jumlah yang lebih besar dibandingkan dengan produk sampingan. Biasanya, produsen hanya memiliki sedikit kendali atas jumlah produk sampingan yang diproduksi.

Produk gabungan diproduksi secara bersamaan melalui proses atau serentetan proses umum, dimana setiap produk yang dihasilkan memiliki lebih dari nilai nominal dalam bentuk sesuai hasil pemrosesan tersebut. Produksi bersifat simultan karena proses produksi menghasilkan seluruh produk tanpa dapat dihindari. Peningkatan dalam salah satu output produk tidak dapat dihindari, akan menyebabkan peningkatan kuantitas dari produk atau produk-produk lainnya, demikian pula sebaliknya, walaupun tidak harus dalam proses yang sama. Titik pisah batas (split-off point) 
didefinisikan sebagai titik dimana produk-produk tersebut dapat dipisahkan sebagai unit-unit individual. Sebelum titik tersebut, produk-produk tadi masih dalam satu kesatuan yang homogen.

Produk sampingan dapat muncul dari pembersihan produk utama, seperti gas dan tar yang muncul dari produksi arang, biasanya gas dan tar yang muncul dari produksi arang, biasanya memiliki nilai sisa. Dalam kasus yang sama, produk sampingan adalah sisa atau sampah, seperti gergaji di tempat penggergajian kayu. Dalam lain produk sampingan muncul dari proses persiapan bahan baku sebelum digunakan dalam proses utama. Pemisahan biji kapas dari kapas, buah apel dari biji apel, dan kulit dari biji coklat merupakan contoh dari produk sampingan jenis ini. Produk sampingan dapat diklasifikasikan menjadi dua kelompok menurut kondisi dapat dipasarkan produk tersebut pada titik pisah batas: (1) yang dijual dalam bentuk asalnya tanpa diproses lebih lanjut, dan (2) yang membutuhkan proses lebih lanjut agar dapat dijual. Biaya gabungan dapat didefiniskan sebagai biaya yang muncul dari produksi secara simultan atas berbagai produk dalam proses yang sama. Setiap kali dua atau lebih produk gabungan atau produk sampingan dihasilkan dari satu sumber daya, maka biaya gabungan terjadi. Mursyidi (2010) menjelaskan biaya bersama (joint cost) atau dikenal juga biaya produksi bersama (joint production cost) adalah biaya produksi yang terdiri dari bahan baku, tenaga kerja langsung dan biaya overhead pabrik yang sama dalam satu kali proses produksi menghasilkan berbagai jenis produk utama.

Biaya gabungan terjadi sebelum titik pisah batas. Biaya gabungan yang terjadi berupa satu jumlah total untuk semua produk yang tidak dapat dibagi, dan bukannya penjumlahan dari biaya individual masing-masing produk. Total biaya produksi dari beragam produk yang melibatkan biaya gabungan maupun biaya produksi individual yang terpisah. Biaya produksi terpisah adalah biaya yang diidentifikasikan dengan produk individual, dan umumnya tidak memerlukan alokasi. Sedangkan biaya produksi gabungan memerlukan alokasi ke produk individual.

Produk gabungan dan produk sampingan sulit dihitung biayanya karena biaya gabungan yang sesungguhnya tidak dapat dibagi, misalnya suatu bijih dapat saja mengandung timah dan tembaga. Dalam kondisi mentah, mineral- mineral ini adalah produk gabungan, sampai dipisahkan oleh pemrosesan bijih. Biaya yang diakumulasikan sebelum titik pisah batas harus ditanggung oleh masing-masing produk berdasarkan selisih harga jual dan biaya untuk menyelesaikan dan menjual setiap mineral setelah titik pisah batas. Oleh karena tidak dapat dibaginya biaya gabungan, metode alokasi yang digunakan untuk menentukan biaya per unit dari produk gabungan bersifat sedikit arbitrer. Perhitungan biaya produk gabungan dan produk sampingan menyoroti masalah pembebanan biaya ke produk asal, penggunaan peralatan, bahan baku, tenaga kerja, dan fasilitas lainnya tidak dapat benar-benar ditentukan. Jika tidak ada persediaan awal maupun akhir, maka laba atau rugi periodik tidak akan dipengaruhi oleh alokasi biaya ke produk gabungan atau produk sampingan, karena biaya-biaya tersebut dibebankan di laporan laba rugi final.

\subsection{Metode Menghitung Biaya Produk Sampingan}

Biaya produksi gabungan tidak dialokasikan ke produk sampingan, metode ini terdiri dari dua metode, yaitu:

a. Metode 1, yaitu pendapatan kotor dari penjualan produk sampingan ditampilkan dalam laporan laba rugi. Pendapatan tersebut dapat dikategorikan sebagai pendapatan lain-lain, tambahan pendapatan penjualan, pengurang harga pokok penjualan dari produksi utama dan sebagai pengurang biaya produksi produk utama.

b. Metode 2, yaitu pendapatan bersih dari produk sampingan (pendapatan dari penjualan produk sampingan dikurangi dengan biaya administrasi dan pemasaran untuk memasarkan produk sampingan, kemudian dikurangi lagi dengan biaya pemrosesan lebih lanjut setelah titik pisah batas) ditampilkan di laporan laba rugi sebagai satu dari keempat kategori untuk metode 1 yang disebutkan diatas.

Biaya produksi gabungan dialokasikan ke produk sampingan, alokasi biaya seperti ini hampir sama dengan perlakuan terhadap produk gabungan. Nilai persediaan didasarkan pada besarnya biaya gabungan yang dialokasikan ditambah dengan biaya pemroses lebih lanjut setelah titik pisah batas. Dalam kategori ini ada dua metode yang digunakan: 
a. Metode 3, metode biaya penggantian;

b. Metode 4, metode nilai pasar, atau yang juga dikenal sebagai metode pembatalan dan pembalikan biaya (reversal cost method).

\section{METODE}

Metode pelaksanaan pengabdian yang akan dilakukan dengan menggunakan metode ceramah, tutorial dan diskusi. Adapun sistematika pelaksanaan kegiatan pengabdian ini adalah sebagai berikut:

a. Langkah 1 (Metode Ceramah)

Peserta diberikan materi mengenai Harga Pokok Produksi.

b. Langkah 2 (Metode Tutorial)

Peserta diberikan contoh ilustratif bagaimana melakukan penyusunan Laporan Harga Pokok Produksi yang benar

c. Langkah 3 (Metode Diskusi)

Peserta pelatihan diberikan kesempatan untuk mendiskusikan permasalahan yang dihadapi berkaitan dengan penyusunan laporan harga pokok produksi BUMDes.

\section{HASIL DAN PEMBAHASAN}

Pengabdian masyarakat Pelatihan Perhitungan Biaya Produk Utama dan Sampingan Pada Badan Usaha Milik Desa di Desa Kerinjing Ogan Ilir diadakan pada hari Kamis, 14 November 2019, kegiatan tersebut dilaksanakan di salah satu kediaman aparatur desa Kerinjing. Pada saat pelaksanaan pertama kali disambut baik oleh warga dengan penuh antusias warga menerima kedatangan kami dengan harapan akan memperoleh ilmu yang bermanfaat untuk kemajuan Desa, kemudian kami dipersilahkan untuk mengambil posisi yang telah warga sediakan. Sebelum acara inti dimulai terlebih dahulu kami di sajikan hidangan khas warga desa kerinjing. Selanjutnya acara dimulai dengan sambutan-sambutan dari Kepala Desa dan Ketua Pelaksana Pengabdian yang dalam hal ini diwakilkan oleh Drs. Burhanuddin, M.Acc, Ak. CA (foto terlampir). Setelah kata sambutan dilanjutkan dengan menyiapkan peralatan seperti pemasangan spanduk dan menyiapkan proyektor/LCD untuk persiapan pemaparan serta pembagian materi kepada warga yang hadir pada kegiatan tersebut.

Materi dalam pengabdian ini disampaikan oleh Sri Maryati, SE., M.Sc, pada saat pemamparan materi warga terlihat focus memperhatikan pemaparan, untuk menambah pemahaman warga diberikan handout slide powerpoint yang di paparkan. Pemaparan berlangsung selama kurang lebih 15 menit kemudian dilanjutkan dengan sesi diskusi berkaitan dengan permasalah yang selama ini di hadapi warga dalam pengakuan hasil penjualan sampingan dari UMKM warga. Secara umum, mereka memberikan statement bahwa hasil produk sampingan tidak diperhitungkan sebagai pendapat UMKM nya (foto terlampir).

Disksusi awal dimulai dari pertanyaan pertama dari warga yang menanyakan contoh produk sampingan yang muncul jika hasil usaha utama lebih kecil dari usaha sampingan? Kemudian pertanyaan kedua dari warga yang menanyakan tentang pengakuan hasil jual produk sampingan mengapa tidak di akui sebagai pendapatan secara umum saja agar lebih simple? Pertanyaan ketiga muncul dari warga terkait pengakuan pendapatan sampingan mengapa dapat diakui sebagai pengurang biaya bukankah itu pendapatan bukan mengeluarkan biaya? (foto terlampir).

Pertanyaan-pertanyaan yang muncul tersebut dijadikan sebagai bahan untuk diskusi lanjutan, pertanyaan tersebut dijawab oleh Bpk Burhanuddin dan Ibu Yusnaini, kemudian meluruskan sudut pandang warga yang dihantarkan pada pengakuan dalam ilmu akuntansi. Kemudian kesimpulan dari hasil diskusi disampaikan oleh Bpk. Arista Hakiki (foto terlampir). 


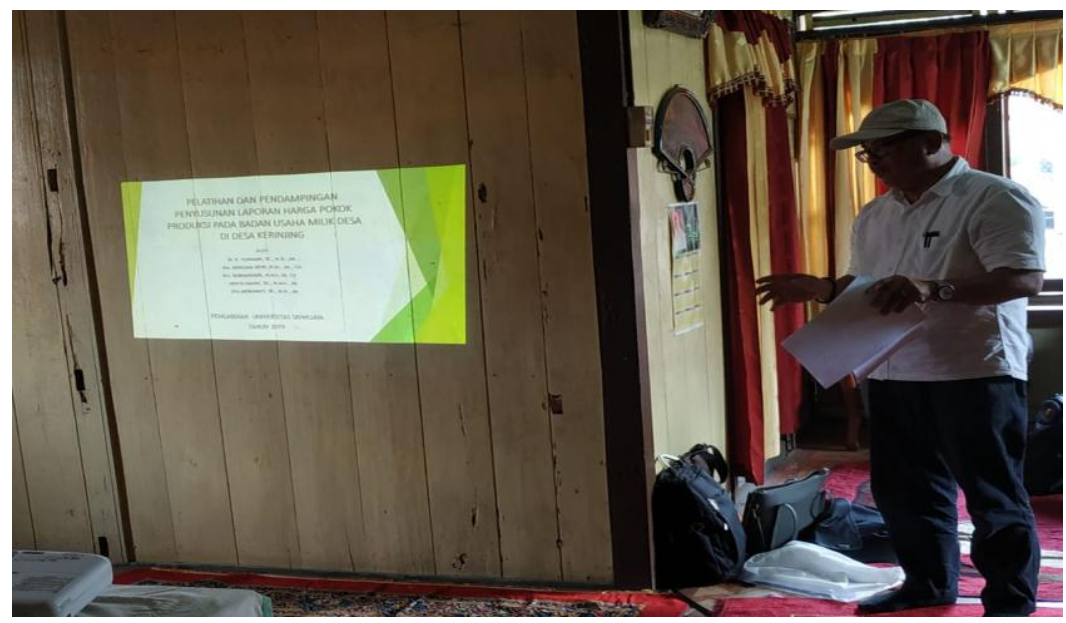

Gambar 1. Penyampaian Materi oleh Narasumber

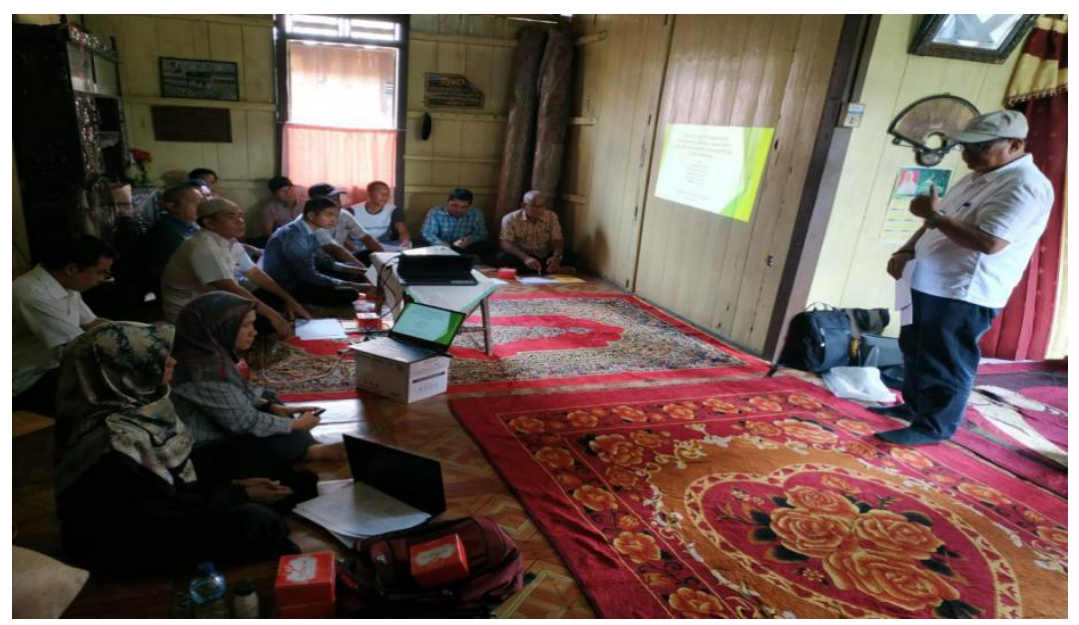

Gambar 2. Kegiatan Diskusi dan Tanya Jawab

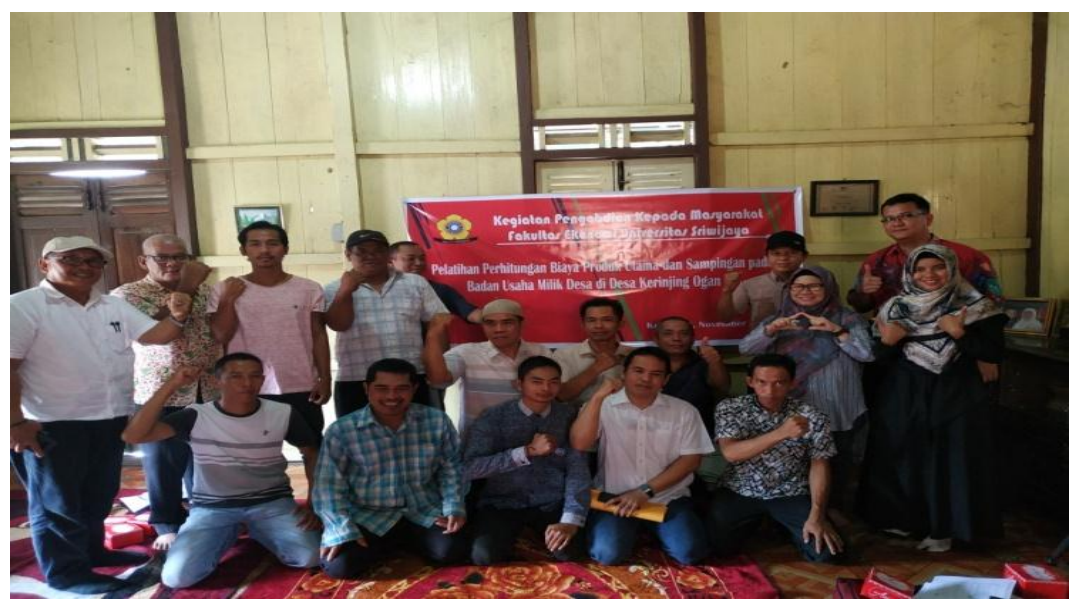

Gambar 3. Foto bersama warga

\section{SIMPULAN}

Kegiatan pengabdian masyarakat dengan judul Pelatihan Perhitungan Biaya Produk Utama dan Sampingan Pada Badan Usaha Milik Desa di Desa Kerinjing Ogan Ilir diadakan pada hari Kamis, 14 November 2019 memberikan kesimpulan bahwa masyarakat Desa Kerinjing memiliki kemampuan mengidentifikasi contoh produk sampingan dari UMKM Desa, cara mengakui penjualan produk sampingan dan cara meminimalkan pengakuan hasil penjualan produk 
sampingan sebagai produk utama UMKM.

Adapun saran pada pengabdian masyarakat ini adalah melakukan pelatihan langsung ke UMKM desa kerinjing terkait satu persatu sehingga setiap kasus penjualan sampingan yang terjadi dapat diidentifikasi. Membuatkan modul contoh langsung laporan pengakuan penjualan produk sampingan UMKM di Desa Kerinjing sebagai dasar untuk beberapa UMKM yang ada di Desa Kerinjing.

\section{UCAPAN TERIMA KASIH}

Ucapkan terimakasih kami sampaikan kepada Fakultas Ekonomi Universitas Sriwijaya yang telah mendanai kegiatan ini dan warga Desa Kerinjing yang begitu antusias dalam menerima kehadiran kami.

\section{REFERENSI}

Blocher, E.J., Chen. K.H., \& Lin, T.W. (2000). Manajemen Biaya: Dengan Tekanan Strategik. Jakarta: Salemba Empat.

Hansen, D.R., \& Mowen, M.M. (2009). Managerial Accounting. Akuntansi Manajeial. Jakarta: Salemba Empat.

Horngren, C.T., Datar, S.M., \& Foster, G.(2008). Akuntansi Biaya: Penekanan Manajerial. Jilid 1. Edisi Kesebelas. Jakarta: PT. Indeks.

Mulyadi. (2007). Akuntansi Biaya. Yogyakarta. YKPN.

Mulyadi. (2010). Akuntansi Manajemen: Konsep, Manfaat dan Rekayasa. Edisi 3. Salemba Empat, Jakarta.

Mulyadi. (2012). Akuntansi Biaya. Edisi Kelima. Yogyakarta: Unit Penerbitan dan Percetakan Sekolah Tinggi Ilmu Manajemen YKPN.

Mursyidi. (2010). Akuntansi Biaya. Cetakan Kedua. Bandung: Refika Aditama.

Kemendagri. (2014). Peraturan Menteri Dalam negeri nomor 113 tahun 2014. Jakarta: Lembaran Berita Negara.

Kemendes. (2015). Permendes no 3 tahun 2015 tentang Pendamping Desa. Jakarta: Lembaran Negara.

Menkumham. (2014). Undang-undang nomor 6 tahun 2014. Jakarta: Lembaran Negara.

Menkumham. (2014). Peraturan Pemerintah nomo 43 tahun 2014 tentang Desa. Jakarta: Lembaran negara.

Setneg. (2014). Undang-undang nomor 23 tahun 2014 tentang Pemerintah Daerah. Jakarta: Kementerian Sekretariat Negara RI.

Sumsel, B. (2015). Sumatera Selatan Dalam Angka. Palembang: Badan Pusat Statistik. 